\title{
Advanced Polymeric Material and Technologies 2010 会議報告
}

\section{1. 全 体 概 要}

2010 年 1 月 24 日から 27 日にかけての 4 日間, Advanced Polymeric Material and Technologies 2010 （APMT 2010）が韓国済州島の The Shilla Hotel Jeju （図 1）にて開催された。済州島は緯度的には宮崎などに近く， 時折冷たい風が吹くものの，比較的暖かく，すごしやすい 気候であった，会場となった Shilla ホテルは済州島の南西 に位置し，北側にある済州空港からは車で一時間ほどであ る. 日本からの参加者は数台のバスで会場へ向かった（主 催者側の配慮からか, 飛行機の座席も APMT 2010 の参加 者がまとまっていて驚かされた)。途中で国立済州博物館 でのツアーが企画されており, 済州島の歴史的文化遺産を 見学することができた。

APMT 2010 は韓国高等科学技術院 (Korea Advanced Institute of Science and Technology : KAIST) と東京工 業大学の二大学間における, 科学交流事業の一環として開 催された。これは韓国科学財団と日本学術振興会のサポー トのもと,「高機能・環境順応型ソフトマテリアル創製と 応用」をテーマとした共同研究を行うもので，平成 17 年 春にスタートし，今年で節目の 10 年目を迎える.さらに

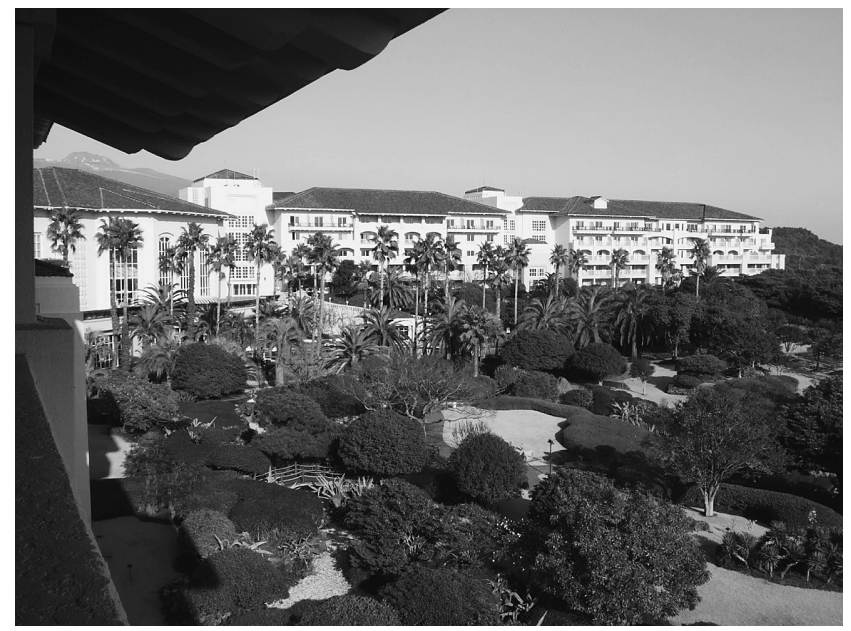

図 1 会場となった The Shilla Hotel Jeju

\footnotetext{
* Suzuki, Hajime/Ito, Hiroshi 山形大学大学院理工学研究科 米沢市城南 4-3-16（９992-8510） 2010.2.12 受理
}

\author{
鈴木 肇*・伊藤 浩 志*
}

セミナーやシンポジウムの開催や研究機関訪問, 両大学院 生の交換留学などを通じて若手研究者の育成にも尽力して いる. 交流事業の詳細については日本学術振興会のホーム ページを参照していただきたい（http：//www.jsps.go.jp /j-bilat/core/index.html). 今回のシンポジウムはその総 括的な意味を含め，日本と韓国のみならず，世界各国から 研究者が集い, 材料合成から物性評価, 成形加工にいたる まで, 最先端の高分子材料に関する幅広い分野の研究発表 がなされた。

初日の 24 日には夕方から Welcome Reception が催され た．会場のあちらこちらで再会を喜ぶ様子がみられ，交流 事業の取り組みを通して多くのつながりが生まれていたこ とを感じた，25日の午前には開会式が行われ，両国のコー ディネータであるSung Chul Kim 教授と柿本雅明教授か らそれぞれ挨拶があり，続いて 3 件の基調講演が行われた (図 2). さらに, Sung Chul Kim 教授から「30 Year's Research at Polymer Engineering Lab., KAIST」と題した 特別講演があった。特に, 非相溶系高分子材料同士の Interpenetrating Polymer Network：IPN に関する研究につ いて焦点を絞った内容であった．Kim 教授は高分子物性, 工学分野では大変著名な先生であり，これまで韓国の高分 子学会や，本学会とも関係が染い国際高分子加工学会 (PPS) の会長も務められた方である.今年で定年される という事もあり，参加者に配布された要旨集の USBメモ リには，これまでの Kim 教授による投稿論文がすべて収

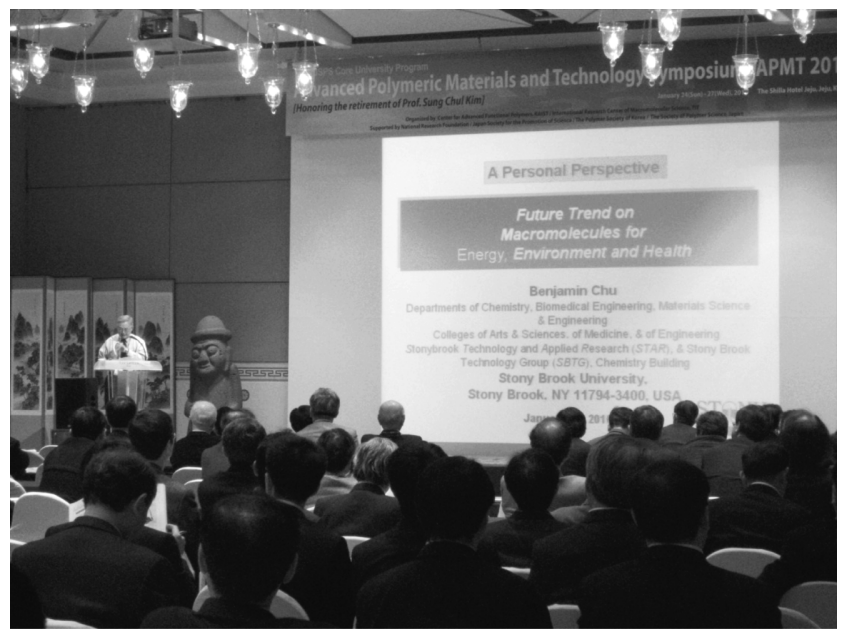

図 225 日午前に行われた基調講演の様子 
められていた。その数, International Journal のみでも 152 報と膨大な数であった。

会議の話に戻そう. 25 日午後からは, 4 セッションに分 かれ，27 日の昼まで各セッションでおよそ 30 件，総計 129 件にもおよぶ講演がなされた。講演者が冒頭の挨拶に加え て, Kim 教授の定年に対する祝辞を述べる様子が多く見 られ, 印象深かった. 特に 25 日の懇親会は, 学生を除く 社会人の参加者によるもので, Kim 教授に対する御祝い のスピーチで 1 時間 30 分にもなった. 参加者はその間, ビール，ワイン，焼酎などを楽しみながら，Kim 教授の スケールの大きさに驚き, また感慨にふけてスピーチを拝 聴した.

講演はその内容によって以下の 5 カテゴリに分類される. · Polymer Chemistry（発表件数 26 件）

- Polymer Physics (発表件数 32 件)

- Polymers for Biomedical \& Environmental Applications（発表件数 32 件)

- Polymers for Information Technology（発表件数 25 件）

- Polymer Nanocomposites（発表件数 14 件)

交流事業のテーマにも組み込まれている，環境順応型材 料として，生分解性材料や生体適合材料に関する報告や情 報デバイスへの応用に関する研究発表があり，高分子材料 の適用範囲の広さを再認識させられる内容であった。

また，26 日夕方にはポスターセッションにて 187 件の 研究発表がなされた.

どの講演も興味をひかれた内容であったが，紙面の関係 上, 聴講した全講演を紹介することは適わないため, 幾つ かの内容について簡単にご紹介させていただく.

\section{2. 高分子複合材料}

Soonho Lim らは超臨界流体を用いた PMMA/Clay のナ ノコンポジット化に関する検討を行った ${ }^{1)}$.

Hydrochlorofluorocarbon（HCFC）はいくつかの高分子 量ポリマーに対して高い溶解性を示すことが知られている. 混練器の高圧セル中を HCFC で満たし， 350 bar まで圧力 を高めて超臨界流体化し，材料中に HCFC を含浸するこ とで，低温・低粘度での混練を行うものである．特に，ク レイとして用いるモンモリロナイトにフッ素化界面活性剤 を用いて表面処理を施し, HCFCに対する親性を付与し た場合の効果についての評価を行い，さらに混練の際，ス クリューに超音波印加する事による擋挥効果についても検 討している.クレイにフッ化表面処理を施すことで, PMMA とのナノコンポジット化が可能となり, また超音 波印加によるクレイの分散効果が大きい事について述べた.

Woo Nyon Kim らは Multi-walled Carbon Nanotube （MWCNT）に過酸化水素による酸化処理と凍結乾燥によ る処理を施し, 分散性の改善を図り, その電気特性やモル フォロジー変化, レオロジー特性を評価した ${ }^{2}$. 処理を施 すことによりCNT の凝集を防ぐ事ができ，複合的なレオ ロジー挙動を示す. さらに電気伝導性, 電磁妨害波遮断性 などが改善される.また処理したものでは含有量増加に伴 い, 急激な電気遮断性の向上がみられ, フィラーの分散状 態制御の重要性が示された。複合材料においてはマトリク ス材とフィラーの界面における接着性が大きく影響を受け
るため，その改善を図ることが重要であると感じた.

筆者らはポスターセッションにて, ポリマー材料と熱伝 導性を有する窒化ホウ素, または窒化アルミニウムを用い てマイクロ/ナノコンポジット化し，その熱伝導性や成形 性に関する発表を行った ${ }^{3)}$. 特に, 射出成形品内部ではせ ん断配向などによるフィラー分布が大きいため，その物性 に及ぼす影響は大きい. この問題を解決するため, 現在は 射出プレス成形の適用により, 成形法からのアプローチに よる制御を試みている。

\section{3. 分子構造制御によるナノ構造化}

ブロック共重合体は基盤との接着性が高いブロック鎖を 優先的に吸着するため，一般的には基盤と水平な方向に層 分離する. しかし Polystyrene (PS) と Poly (methyl methacrylate) (PMMA) ブロック共重合体の薄膜では, PMMA 成分が凝集し，基盤と垂直な方向にシリンダー構造を形成 することが知られている. 紫外線照射などにより, PMMA 成分を除去すれば，ナノポーラス構造を有するテンプレー トとしての応用が可能である. KAIST の Sang Youl Kim らはリビングラジカル重合の一種である Reversible Addition-Fragmentation Chain Transfer (RAFT: 可逆的付 加開裂連鎖移動) 重合と Atom Transfer Radical Polymerization（ATRP：原子移動ラジカル重合）により，櫛-コ イル状ブロック共重合体である, poly (methyl methacrylate $)-\mathrm{b}$ - poly (2-(2-bromopropionyloxy $)$ - ethyl acrylate)-g-polystylene (PMMA-b-PBPEA-g-PS) を合 成した。そして, PS 分子鎖の長さが異なる試料を比較す る事で, 最適な分子設計について検討を行った ${ }^{4}$. AFM などによる評価から，PS 成分の体積比が $75 \%$ となる時， PMMA-b-PBPEA-g-PS がシリンダー構造を形成するこ とが報告された.

感光性樹脂の利用によるホログラフィック記録デバイス は, 光の効率的な制御が可能であるため, 超高密度データ ストレージや高効率エネルギーデバイスなどへの応用が期 待され, 注目を集めている. Jung-Ki Park らは感光性樹 脂を用いた，有機/無機ハイブリッド IPNをゾルーゲル反 応により作製した5)。エポキシ樹脂中に無機ネットワーク 構造を形成する alkoxysilane (3-aminopropyl) triehoxysilane (APTES) を導入することで, 光重合の際に生じ る体積収縮を低減することができる. APTES 含有量が7 $\mathrm{wt} \%$ の時に IPN 構造を形成することが示された。さらに, 光の照射による回折格子やホログラフィック記録デバイス の作製を実現した。

\section{4. 医療・情報分野への応用}

磁性ナノ粒子をポリマーで被覆し，その表面を修飾する ことでガン遺伝子の検知などへの応用が可能である．Lalida Charoenmark らは有機酸を安定剤として, Poly（styrene-co-acrylic acid) (PS/AA) 中に磁性ナノ粒子を分散 させたナノ粒子をミニエマルション重合により作製し，ス チレンと磁性粒子の量による影響を調べた ${ }^{6)}$. 直径数十 $\mathrm{nm}$ サイズの PS/AA 粒子中に直径 $10 \mathrm{~nm}$ ほどの磁性粒子が均 一に分散している様子が示され, さらにその結晶構造や磁 気特性について報告した。 
K. Koyama らは，ICチップ積層の際に，その接着フィ ルムとして用いられる $\mathrm{SiO}_{2} /$ Acrylic Polymer/Epoxy（AP (EP) 高分子複合材料の成形不良に着目し, そのレオロジー 挙動の評価を行った ${ }^{7)}$. $\mathrm{SiO}_{2}$ の含有量を変化させた系の各 温度における周波数分散測定結果から， $100^{\circ} \mathrm{C}$ では $\mathrm{SiO}_{2}$ 体積比が $35 \%$ 以上となる時にゲル化が生じ，また伸長粘 度測定から，高温では歪み硬化性を示し，低温では歪み軟 化性を示す様子が示された.この結果からレオロジー挙動 の評価より，適切な材料設計に関する知見が得られること が示された。

\section{5. 最 後に}

東京工業大学と KAIST による，共同研究から得られた 多くの知見が発表された。本プログラムは，目的である日 韓の科学技術的交流や若手研究者の育成に限らず，高分子 材料研究への寄与は計り知れないものがあると考える. 本 プログラムを基盤として, 新たな共同研究が生み出され, さらなる発展を遂げていくであろうことを期待している.

\section{参 考 文 献}

1 ) Hyun-Tack Jung, Sang-Soo Lee, Min Park, Junkyung Kim, Soonho Lim : Preparation of PMMA /Clay Nanocomposites Using Supercritical Fluid, PN 10
2) Mi Sun Han, Yun Kyun Lee, Heon Sang Lee and Woo Nyon Kim : Effect of Multi-walled Carbon Nanotube Dispersion on the Electrical and Morphological Properties of Polycarbonate/Multi-walled Carbon Nanotube Composites, PN 02

3 ) Suzuki, H., Watanabe, T., Matsushita, Y., Yamazaki, M., and Ito, H. : Thermal Properties and Surface Replication of Nanocomposites Micromoldings, PS 142

4 ) Myungeun Seo, Seonhee Shin, Mihee Moon and Sang Youl Kim : Synthesis and Surface-independent Vertical Orientation of Comb-coil Type Diblock Copolymers, PC 03

5 ) Jung-Ki Park, Seungwoo Lee, Jihye Lee : Application of Photopolymers to Nanostructured Devices, PI 07

6 ) Lalida Charoenmark, Pramuan Tangboriboonrat, Kulachart Jangpatarapongsa, Duangporn Polpanich: Development Of Magnetic Nanoparticle For Gene Detection In Cancer, PB 18

7 ) Koyama, K., Uematsu, H., Sugimoto, M., Iwakura, T. and Inada, T. : Rheology of $\mathrm{SiO}_{2}$ / (Acrylic Polymer) Epoxy) Multi-component Material used for Semiconductor Device, PP 02

\section{賛助会員の皆様へ \\ 「製品・技術紹介」へご投稿下さい}

「成形加工」誌には，「製品・技術紹介」のコーナーを設けています.

「製品・技術紹介」はプラスチック成形加工学会の賛助会員が自社の製品・技術を広く会員に アピールするための記事で，詳細は以下のとおりです.

1 . 賛助会員企業の開発した装置・機械・材料等，各種製品と技術を資料・図表・写真等によ り紹介するもの.

2. 賛助会員企業に属する個人（または複数名）の記名入り記事とし，長さは刷上がり 1 頁と する（図表を含み 2300 字程度，原稿 1 頁当たり 26 字 $\times 27$ 行 $=702$ 文字で作成）.

3. 掲載料は無料（ただしカラー印刷の場合は実費負担）.

この「製品・技術紹介」への投稿を，是非ご検討下さい.

「製品・技術紹介」は，投稿順（抜閲後）に随時掲載しております。記事のスタイル，内容等 につきましてはすでに掲載されている幾つかの記事をご参照下さい.

「成形加工」編集委員長 大嶋正裕 